\title{
Development of Instant Linear Gel for Coal Bed Methane Gas Operations
}

\author{
Ramana Murthy RVV, ${ }^{1 *}$ Murthy KSR, ${ }^{2}$ Murthy Chavali ${ }^{3}$ \\ ${ }^{1}$ NTRC-MCETRC and 109 Nano Composite Technologies Pvt. Ltd., India \\ ${ }^{2}$ Department of Applied Chemistry, University of Petroleum and Energy Studies, Energy Acres, Bidholi Campus, Premnagar, India \\ ${ }^{3}$ Division of Chemistry, Department of Science, Faculty of Science \& Technology, Alliance University, India
}

\begin{abstract}
Previously we prepared fracturing linear gel with fossil diesel, bio-diesel and also used suspending, anti-settling agents and emulsifiers. But through this research, a novel and efficient method for the preparation of linear gel directly mixed with water, guar gum and sodium acetate together instantly. In this instead of diesel, we used water and no need to mix anti-settling agents, suspending agents, emulsifiers that resulted in 30 viscosity linear gel. Ammonium persulphate or Ammonium peroxidisulphate and enzyme-G are used for oxidation purposes to break the gel gradually at a particular static temperature. The degradation pattern observed from the breaker test showed that a reduction in gel viscosity depends on time, temperature \& breaker concentration. Observations from experiments revealed that a small concentration of breakers provides rapid break compared to oxidative breakers. This article, designing of fracturing fluids describes how to use the fluid's viscosity generated by the gelling agents like guar gum for CBM operations.
\end{abstract}

Keywords: Breakers, CBM operation, Fragmentation, Linear gel, Viscosity properties

\section{Introduction}

Hydraulic fracturing typically involves millions of gallons of fluid that are pumped into oil or gas wells at high pressure to create fractures in the rock formation that allow oil or gas to flow from the fractures to the wellbore. ${ }^{1}$ The main functions of fracturing fluids are to open the fracture and to transport propping agents along the length of the fracture. They are four types of fracturing i.e. water fracturing, gelled fluids, linear gels, crosslink gels. ${ }^{2}$ The chemistry of commonly used fracturing fluids and additives are guar Figure 1. Guar has a long polymer chain and high molecular weight Figure 2. Gymer composed of Mannose and galactose sugars has a high affinity for water. When the powder is added to water, the guar particles swell and hydrate, which means the polymer molecules become associated with many water molecules and unfold and extend out into the solution which tends to overlap and hinder motion, which elevator the viscosity of the solution. ${ }^{3}$

The guar polymer has chemicals added to the fracturing fluids include friction reducers, surfactants, gelling agents (guar gum), scale inhibitors, acids, corrosion inhibitors, antibacterial agents. Depending on the site, $15-80 \%$ of the fracturing fluid injected is recovered as flow backwater at the wellhead. ${ }^{4}$ Biocides/Bactericides are added to minimize the enzymatic attack of the polymers used to gel the fracturing fluid by aerobic bacteria present in the base water. ${ }^{5}$ Agro material while preparation of frac concentration should be in basic nature. So we can use Sodium bicarbonate or sodium acetate is mixed in the concentration to maintain the $\mathrm{pH} .{ }^{6}$ Usually, the gelling agents in fracturing fluids are guar gum derivatives such as hydroxyl propyl guar and carboxymethyl hydroxyl propyl guar

\begin{tabular}{|l|l|}
\hline Quick Response Code: & *Corresponding author: Ramana Murthy RVV, NTRC-MCETRC and 109 Nano Composite \\
Technologies Pvt. Ltd., Guntur District, Andhra Pradesh, INDIA \\
Received: 10 November, 2021 \\
Citation: Ramana Murthy RVV, Murthy KSR, Chavali M. Development of Instant Linear Gel for \\
Coal Bed Methane Gas Operations. Trends Petro Eng. 2021;1(3):1-5. DOI: \\
\hline $10.53902 / T P E .2021 .01 .000511$
\end{tabular}


(or) cellulose derivatives such as carboxyl methyl guar, hydroxyl ethyl cellulose, hydroxypropyl cellulose, xanthan gum. ${ }^{7}$ Before stating frac operation need to add biocide (anti-bacterial agent in water tanks, it will control the growth of micro-organisms will quickly degrade the polymer to a non-functional level. ${ }^{8}$ So the addition of biocides and bactericides to fracturing fluids will prevent the introduction of anaerobic sulphate reducing bacteria (SRB) into the reservoir. ${ }^{9}$

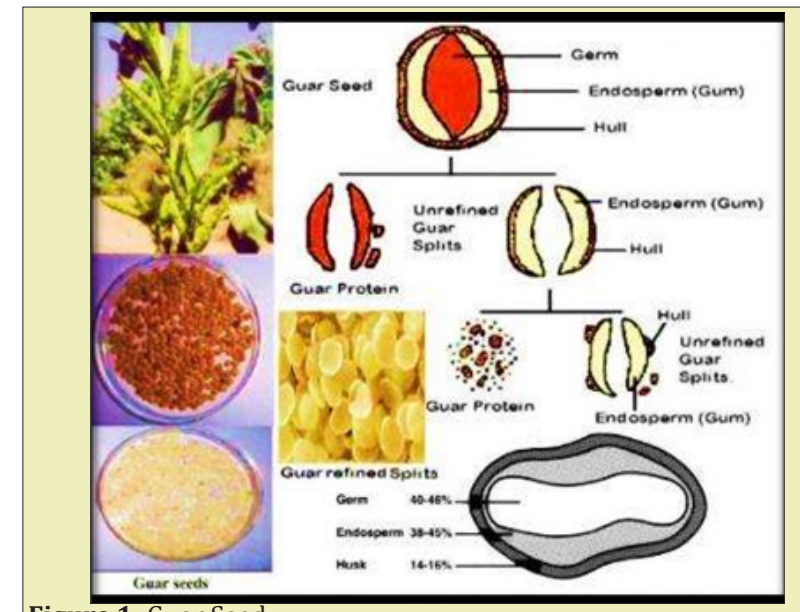

Figure 1: Guar Seed.

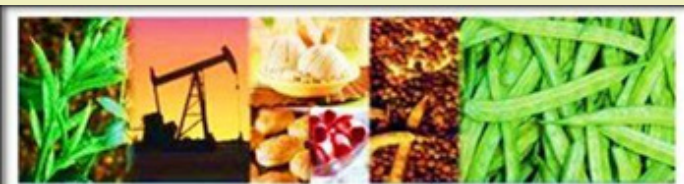

Chemical Structure of Guar Gum
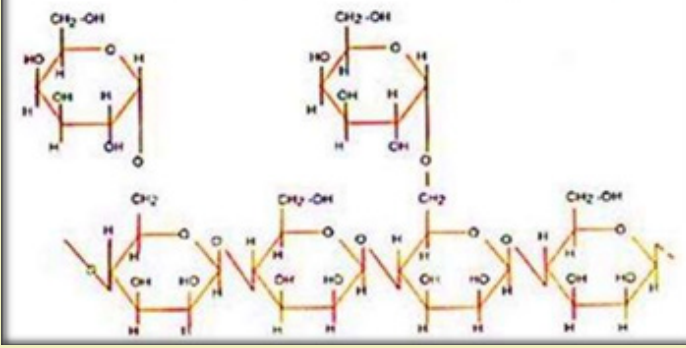

Figure 2: Chemical structure of guar gum.

Guar galactomannan is a plant polysaccharide with extensive applications in the food, paper, and textile and petroleum industries. ${ }^{10}$ The main advantages of using guar are its low cost, easy availability and capacity to form viscous solutions and gels at low concentrations. Additionally, the chain architecture of guar galactomannan can be selectively modified to tailor the properties of guar formulations and open up new opportunities for guar usage. ${ }^{11}$ In many types of shale, proppant conductivity drops considerably in the presence of water because the rock-fluid interactions soften the rock leading to proppant embedment. ${ }^{12}$ The fracturing treatments require a higher viscosity fluid, such as linear fracturing fluids. ${ }^{13}$ These are formulated by adding a wide array of different polymers to water ${ }^{14}$ Such polymers are dry powders that swell when mixed with an aqueous solution and form a viscous gel. ${ }^{15}$ Linear gels control fluid loss very well, whereas in higher permeability formations fluid loss can be excessive. ${ }^{16,17}$ Linear gels tend to form thick filter cakes on the face of lower-permeability formations. ${ }^{18}$ So this study provides focuses on the way to mix the fracturing fluid, how Linear gel hydrating and how to perform breaker test. ${ }^{19,20}$ In general, a fracturing fluid can be thought of as the sum of three main components:

Fracturing Fluid $=$ Base Fluid + Additives + Proppant

\section{Materials and Methods}

\section{Experimental}

- $\quad$ Production water

- $\quad$ Sodium bicarbonate or sodium acetate as a buffering agent.

- $\quad$ Guar gum powder Figure 3.

- $\quad$ Two breakers, Ammonium per Sulphate which is in solid-state and another one is liquid Hemicellulase enzyme-G.

- Gas flow which is in a liquid state (the composition of Methanol 2-Butoxyethanol Ethylene oxide nonylphenolpolymer Alcohols, C12-16, ethoxylated Tridecyl alcohol Nonylphenol Ethoxylated nonionic surfactant). It will flow back after fracturing. Biocide is a composition formed from ingredients comprising peroxide and hypochlorite.

- $\quad 20 / 40$ size proppant.

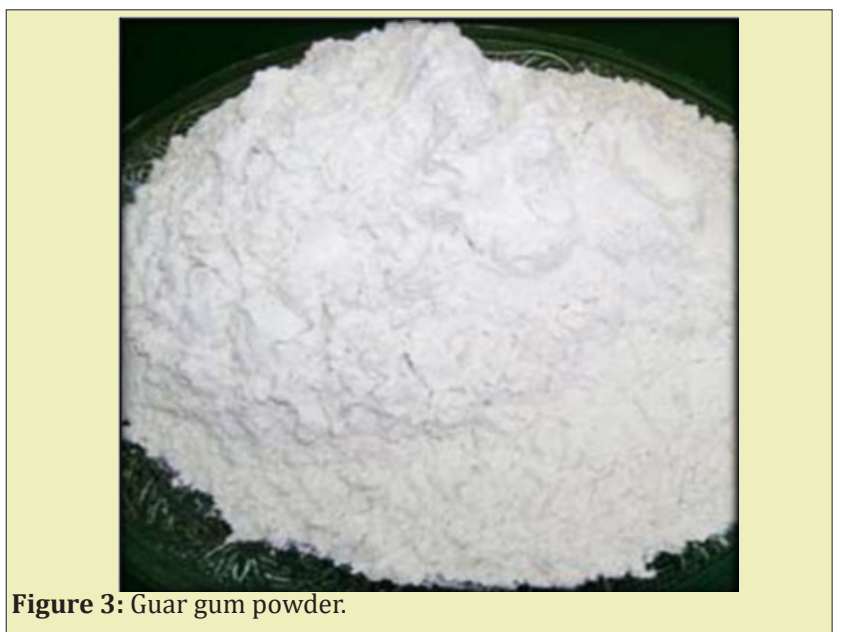

\section{Water Analysis}

Usually, for every linear gel testing, we should check water quality because parameters of water will affect more during the formation of gel Hydration. If water has more $\mathrm{pH}$, hardness, chlorides, iron leads to gel break very quickly. The following parameters should check before testing as shown in Table 1. The water should be colourless, the turbidity of water should be low and the $\mathrm{pH}$ value should be 6-8. The chloride is determined by titration meth- 
ods or chloride strips. The chlorides should be in the range up to $<800 \mathrm{ppm}$. Iron can check by using an electronic instrument. Iron should be range up to $<10 \mathrm{ppm}$. Hardness can check by titration method and it should be in the range up to $<100$ ppm. Bicarbonate should be range $<1000 \mathrm{ppm}$. Sulfates should be range $<300 \mathrm{ppm}$. TDS should be range $<50,000 \mathrm{ppm}$. The reducing agent should be negative. Bacteria should be range $<800,000$. Specific Gravity of water can be determined by Hygrometer. Biocide should be added to the water sample before testing to kill any bacteria.

Table 1: Test1 (sample water).

\begin{tabular}{|c|c|}
\hline Parameters & Measured values \\
\hline Clarity, colour, odour & Clear \\
\hline Sample temperature, ${ }^{\circ} \mathrm{C}$ & 26 \\
\hline Specific gravity & 1 \\
\hline Initial pH & 7.5 \\
\hline${\text { Iron }\left(\mathrm{Fe}^{2+} / \mathrm{Fe}^{3+} \text { ) ppm }\right.}$ & 1 \\
\hline Chloride, ppm & 400 \\
\hline Total Hardness, ppm & 80 \\
\hline Bicarbonate, ppm & 800 \\
\hline Sulphates, ppm & 200 \\
\hline TDS, ppm & 30,000 \\
\hline Reducing Agent & Negative \\
\hline Bacteria & $5,00,000$ \\
\hline
\end{tabular}

\section{Viscosity Measurement}

A direct viscosity reading in centipoises (cp) was obtained by taking the 300-rpm reading of the VG meter with Rheometer (FI spring, BI bob and Rotor). The viscosity of gel was measured when the gel exhibit stringy and pourable behaviour. So, the apparent viscosity of gel was determined using the Fann 35 Rheometer.

\section{Procedure for preparation of $\mathbf{1 0 0 0} \mathrm{ml}$ gel hydration}

Taking $309 \mathrm{ml}$ of production water into Blender ought to look after velocity (1900-2000rpm). Add 60 grams of Buffering agent like sodium hydroxide (or) sodium Bicarbonate (or) sodium acetate which should be in a powder state, mix until the material is dispersed and lump-free for 15 minutes. After mixing the buffering agent, the slurry should be maintained in basic nature Figure 4 . Need to check the basic nature by placing a pH strip into the slurry. Now add 240 gm of guar gum and continue the mixing for 20 minutes (or) until the concentration of slurry is smooth and lump-free. Measure the density of the slurry. If the density of the slurry varies more than $0.1 \mathrm{ppg}$, refer to "cut back (or) weight-up" charts to correct the slurry density. Measure the viscosity of the slurry, it should be maintained at 30-32 viscosity to pump the slurry.

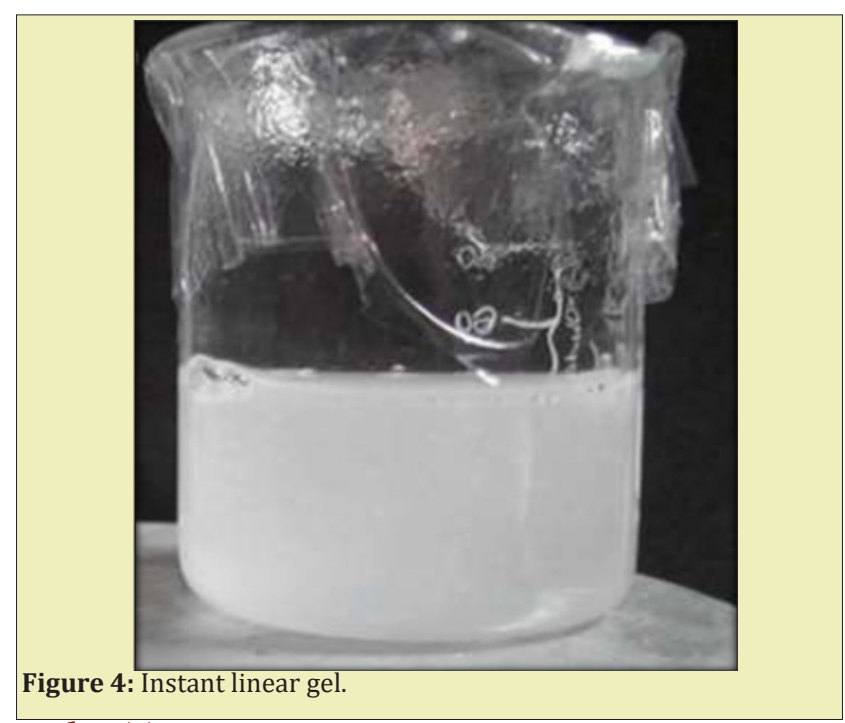

\section{Breaker Test}

\section{Unit conversions}

$1 \mathrm{ppt}=\frac{1 \text { pound }}{(1000 \times 1 \text { gallon })}=\frac{1 \times 453.2}{(1000 \times 1 \times 3.782)}=\frac{453.2}{3782}=0.12 \mathrm{gms} / \mathrm{lit}$

Where 453.2 grams is a factor, 1 gallon $=3.782$ lit

$$
1 \text { gpt }=\frac{1 \text { gallon }}{1000 \text { gallons }}=\frac{1 \mathrm{ltr}}{1000 \mathrm{ltr}}=\frac{1 \mathrm{ml}}{1000 \mathrm{ml}}
$$

Now add ppt ammonium persulphate and 1gpt Enzyme-G into a linear Gel glass bottle and mix it well. Put it in water baths which are maintained at $60^{\circ} \mathrm{C}$ and $45^{\circ} \mathrm{C}$ temperature, now check the viscosity for every 10 minutes.

\section{Fragmentation reaction}

Initially, the gel viscosity is 30 , under the gas well the bottom hole circulating temperature is $45^{\circ} \mathrm{C}$ and $60^{\circ} \mathrm{C}$, by using $1 \mathrm{ppt}$ ammonium persulphate and 1gpt Enzyme-G breaker concentrations the fragmentation takes place, it means the gel viscosity will break gradually based on these temperatures and breaker concentration. If we want to break the gel viscosity very quickly, we can increase the breakers concentration.

\section{Fragmentation}

\section{$\mathrm{X}-\mathrm{Y} \rightarrow \mathrm{X}+\mathrm{Y}$ \\ $X-Y$ fragments to $X$ and $Y$}

In Table 2 we observed for every 10 minutes gel breaks gradually up to 180 minutes. Usually, the slurry pumping time is near to 30 minutes approximately. So, in hydro frac operation, the gel carries 20-40 size sand, breakers, and gas flow solution injected into well under high-pressure forms fissures. After the slurry is pumped (i.e., after 30 minutes) the fragmentation reaction takes place, the 
breakers act on gel under bottom hole circulating temperature, 30 viscosity linear gel becomes watery gradually Figure 5. After 180 minutes the gel totally will break and become water, the gas flow will return as flow backwater. This flow back water again we can use for production water after reverse osmosis process.

Table 2: Test-2 Breaker Test Result (7.5 gpt gel under breaker concentration at 1 ppt oxidizer and 1gpt Enzyme-G).

\begin{tabular}{|c|c|c|c|}
\hline \multirow[t]{2}{*}{ S. No } & \multirow{2}{*}{$\begin{array}{l}\text { Gel Breaking } \\
\text { Time } \\
\text { (minutes) }\end{array}$} & \multicolumn{2}{|c|}{$\begin{array}{c}\text { Linear gel viscosity } \\
1 \text { ppt and } 1 \text { gpt breaker }\end{array}$} \\
\hline & & $60^{\circ} \mathrm{C}$ & $45^{\circ} \mathrm{C}$ \\
\hline 1 & 0 & 30 & 30 \\
\hline 2 & 10 & 27 & 28 \\
\hline 3 & 20 & 25 & 26 \\
\hline 4 & 30 & 23 & 24 \\
\hline 5 & 40 & 20 & 21 \\
\hline 6 & 50 & 17 & 19 \\
\hline 7 & 60 & 15 & 17 \\
\hline 8 & 90 & 11 & 14 \\
\hline 9 & 120 & 8 & 10 \\
\hline 10 & 150 & 5 & 7 \\
\hline 11 & 180 & 0 & 2 \\
\hline
\end{tabular}

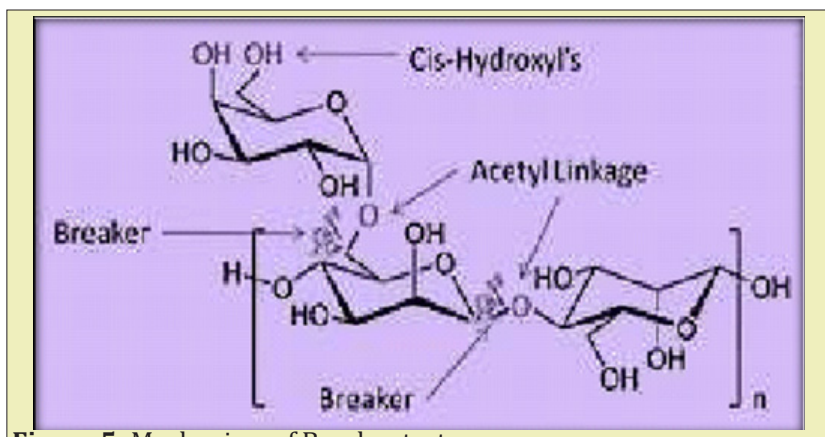

Figure 5: Mechanism of Breaker test.

\section{Conclusion}

The main focus of this research was to avoid pollution in extreme operations, because of frac operation environment should be eco-friendly and naturally. The first objective of this research was the instead of hydrocarbons diesel, we used water for the preparation of linear gel. This is a direct mixing method; this linear gel effectively works in frac CBM onshore and offshore operations. Here less quantity of oxidizing agents (breakers) consumption take place. The main benefit is economically very less for frac operations.

We conclude from the above experiment that without using any hazardous chemicals for preparation of linear gel observed good viscosity properties at bottom hole static temperature. This experiment is eco-friendly; the linear gel can also keep continuously in hydration tanks for 22 hours. So, we can pump directly into well with high pressure and the used chemicals are very less hazardous. No smoke point for this linear gel because the gel was prepared with water. So, when compared with hydrocarbons diesel liner gel this water gel has many advantages in all aspects and is worthless for extreme operations.

\section{Acknowledgements}

The authors (s) wish to express their appreciation to the BHI services frac Department, Essar oils for supporting their research project by providing the chemicals. We also express our Thanks to lab team members for assisting with this research.

\section{Funding}

None.

\section{Conflicts of Interest}

Author declares that there is no conflict of interest.

\section{References}

1. Michael Berry Smith, Carl T. Montgomery, Hydraulic Fracturing, CRC Press, BocaRaton, 2015:33-38.

2. Ching $\mathrm{H}$ Yew, Xiaowei Weng. Mechanics of Hydraulic Fracturing, $2^{\text {nd }}$ Edition, Elsevier Inc., USA, 2015.

3. Ramana Murthy RVV, Murthy Chavali, Naresh Kumar Katari. Materials Today: Proceedings. 2016; pp. 3792.

4. Hariharan AVLNSH, Murali Krishna D. Analysis of Heavy Metals in the Vicinity of Waltair Sea Coast, Visakhapatnam Dt. (A.P.). J Applicable Chem. 2012;1(1):39-43.

5. Bikales Mark, Overberger, Georg Menges. Encyclopaedia of Polymer Science and Technology. $2^{\text {nd }}$ Ed, John Wiley and Sons Inc., 1987; 7:587635.

6. M Umayavalli1, N Krishnaveni, G Siva Kumar. Kinetics of Polymerization of Methacrylic Acid Monomer Initiated by Peroxo Disulphate-N,N,N'N'-Tetramethyl ethylenediamine. J Applicable Chem. 2013;2(6):1701-1704.

7. Wang Q, Peter R Ellis, Simon B Ross-Murphy. The dissolution kinetics of guar gum powders-III. Effect of particle size, Carbohyd Polym. 2006;64(2):239-246.

8. Jyoti kundal, Reena Purohit, Rajendra Singh, et al. Antimicrobial and Antioxidant Activities of Bark Extract of Myrica Esculenta. J Applicable Chem. 2013;2(5):1141-1146.

9. Edrisi AR, Kam SI. A New Foam Rheology Model for Shale-Gas Foam Fracturing Applications, SPE Canadian Unconventional Resources Conference, Society of Petroleum Engineers, (Calgary, Alberta, Canada), 2012.

10. Taylor RS, Lestz RS. Liquid Petroleum Gas Fracturing Fluids for Unconventional Gas Reservoirs, Canadian International Petroleum Conference, Society of Canada, (Calgary, Alberta), 2006.

11. Brannon HD, Kendrick DE, Luckey E, et al. Multi-Stage Fracturing of Horizontal Wells Using Ninety-Five Quality Foam Provides Improved Shale Gas Production, SPE Eastern Regional Meeting, Society of Petroleum Engineers, Charleston, West Virginia, USA, 2009.

12. Wen Chen, Olivier Maurel, Experimental study on an alternative oil stimulation technique for tight gas reservoirs based on dynamic shock waves generated by Pulsed Arc Electrohydraulic Discharges. Journal of Petroleum Science and Engineering. 2012;88-89:67-74.

13. Leiming Li, Ghaithan A, Al Muntasheri, et al. A review of crosslinked fracturing fluids prepared with produced water. Petroleum. 2016;2(4):313-323. 
14. Gupta S, Carman PS. Associative Polymer System Extends the Temperature Range of Surfactant Gel Frac Fluids. SPE International Symposium on Oilfield Chemistry, Society of Petroleum Engineers, (The Woodlands, Texas, USA). 2011;SPE-141260-MS.

15. Hyne NJ. Nontechnical Guide to Petroleum Geology, Exploration, Drilling and Production, Pennwell Books, $2^{\text {nd }}$ edition, 2001.

16. Georgi E Chernev, Lyudmila V Kabaivanova, Isabel M Miranda Salvado, et al. Sol-Gel Hybrid Materials Applied as Matrices for A Co-Immobilized System of Bacteria and Algae. J Applicable Chem. 2013;2(6):16651673.

17. A Rajendiran, K Krishnasamy, S Kabilan1, et al. Dielectric and viscosity studies of some Petroleum-based lubricating base oils. J Applicable Chem. 2013;2(2):264-270.
18. James G. Speight. Handbook of Hydraulic Fracturing, John Wiley \& Sons Inc., New Jersey, 2016, p. 150-200.

19. Ramana Murthy RVV, Naresh Kumar Katari, P Satya Karuna, et al. Preparation of Cross Linker Liquid Frac Concentration (XLFC-1B) with different Hydrocarbons like Petrol, Diesel, Kerosene compatibility\& Breaker Test by using oxidiser, breakers. J Applicable Chem. 2013;2(3):605-613.

20. Robert B Laughlin. Evaluation of Impacts to Underground Sources of Drinking Water by Hydraulic Fracturing of Coalbed Methane Reservoirs, Chapter 4, United States EPA, 2004; p. 1-26. 